\title{
Physico-Chemical Features of the Kpassa Reservoir, Northern Benin, with Emphasis on Its Trophic State: A Preliminary Study
}

\author{
Ousmane Touré Boukari1 ${ }^{*}$, Daouda Mama1, Youssouf Abou², Moctar Limam Bawa3 \\ ${ }^{1}$ Laboratory of Applied Hydrology, Department of Hydrology and Integrated Management of Water Resources, National Institute of \\ Water, University of Abomey-Calavi, Abomey-Calavi, Benin \\ ${ }^{2}$ Laboratory of Ecology and Aquatic Ecosystem Management, Department of Zoology, Faculty of Sciences and Technics, \\ University of Abomey-Calavi, Abomey-Calavi, Benin \\ ${ }^{3}$ Laboratory of Water Chemistry, Department of Chemistry, Faculty of Sciences, University of Lomé, Lomé, Togo \\ Email: *oboukari3@gmail.com
}

How to cite this paper: Boukari, O.T., Mama, D., Abou, Y. and Bawa, M.L. (2016) Physico-Chemical Features of the Kpassa Reservoir, Northern Benin, with Emphasis on Its Trophic State: A Preliminary Study. Journal of Environmental Protection, 7, 20672080.

http://dx.doi.org/10.4236/jep.2016.713161

Received: November 13, 2016

Accepted: December 23, 2016

Published: December 26, 2016

Copyright $\odot 2016$ by authors and Scientific Research Publishing Inc. This work is licensed under the Creative Commons Attribution International License (CC BY 4.0).

http://creativecommons.org/licenses/by/4.0/

(c) (i) Open Access

\begin{abstract}
This work presents recent data on the physico-chemical properties and the trophic status of Kpassa reservoir at eighteen locations from August 2014 to February 2015. Seventeen physico-chemical parameters were measured and data obtained were statistically analyzed. The descriptive statistics showed their variations (minima-maxima) as follows: $\mathrm{pH}(4.65-7.30)$, temperature $\left(25.1^{\circ} \mathrm{C}-29.9^{\circ} \mathrm{C}\right)$, dissolved oxygen $(1$ - $5.79 \mathrm{mg} / \mathrm{L})$, oxydability $(0.32-10.88 \mathrm{mg} \mathrm{O} / \mathrm{L})$, electrical conductivity (55 - 77 $\left.\mu \mathrm{S} / \mathrm{cm}^{-1}\right)$, TDS $(76-94 \mathrm{mg} / \mathrm{L})$, turbidity $(15.70-274.40 \mathrm{NTU})$, transparency $(0.24$ $1.55 \mathrm{~m})$, suspended matter $(3-92 \mathrm{mg} / \mathrm{L})$, total phosphorus $(0.25-1.90 \mathrm{mg} / \mathrm{L})$, orthophosphate $(0.08-0.61 \mathrm{mg} / \mathrm{L}$ ), nitrate (undetected $5.50 \mathrm{mg} / \mathrm{L}$ ), nitrite (undetected $0.79 \mathrm{mg} / \mathrm{L}$ ), ammonia (undetected $0.36 \mathrm{mg} / \mathrm{L})$, chlorophyll a $(7.20-2334.6 \mu \mathrm{g} / \mathrm{L})$, silica $(4.34-15.67 \mathrm{mg} / \mathrm{L})$ and N/P ratio $(0.08-42.62)$. These parameters were mainly influenced by agricultural activities and climatic conditions. The restriction or the removal of the use of chemical fertilizers in agricultural activities in Kpassa reservoir basin was recommended. The highest values of Pearson and Spearman correlations were observed across TDS and conductivity $(0.967 ; 0.951)$, turbidity and oxydability (0.924; 0.665$)$, turbidity and chlorophyll a $(0.884 ; 0.663)$, turbidity and suspended matter $(0.982 ; 0.793)$, suspended matter and transparency $(-0.781 ;-0.819)$, suspended matter and nitrate $(-0.813 ;-0.839)$, suspended matter and oxydability $(0.919 ; 0.602)$ and suspended matter and chlorophyll a $(0.879 ; 0.656)$. Carlson's trophic state index (TSI) values varied between 36 and 66 showing that Kpassa reservoir was eutrophic in August and mesotrophic to oligotrophic during the other months of the sampling period. ANOVA and Kruskal-Wallis test indicated that there were no significant differences between sampling stations.
\end{abstract}




\section{Keywords}

Physico-Chemical Features, Trophic State, Kpassa Reservoir, Okpara River, Benin

\section{Introduction}

There are many things that people need to survive, one of which is water. The need for water in the day to day activities of man includes for cooking, washing, drinking and for industrial activities [1]. In most urban-rural communities in the developing countries especially the Sub-Saharan Africa, surface waters (rivers, streams, and lakes among others) have been the most available sources of water used for domestic purposes [2]. With the development of civilization, increasing industrialization and application of various fertilizers, pesticides, careless dumping, discharge of solids and liquids water sources, the Earth planet is continuously getting polluted conducing various sources water unfit for use [3]. One of the most important environmental problems in river water quality is eutrophication [4] [5]. In Poland, as defined in the act of the Water Law [6], eutrophication is the enrichment of the water with nutrients, especially nitrogen and phosphorus compounds, which cause accelerated growth of algae and higher forms of plant life, as a result of which undesired disturbances of water ecosystems and the deterioration of water quality take place [7]. The water becomes turbid with decaying organic matter from plants and animals and the supply of dissolved oxygen in the water becomes depleted by the rapidly growing plants. The absence of oxygen causes anaerobic bacteria to attack organic matter thus releasing hydrogen sulphide [8]. Water quality monitoring is an essential tool used by environmental agencies to gauge the quality of surface water and to make management decisions for improving or protecting the intended uses [9]. Several indicators, indexes and models have been developed to assess eutrophication and water quality in aquatic ecosystems based on chemical, physical and biological parameters [10]. Trophic state index is one of the most effective tools to communicate information on water quality to the concerned citizens and policy makers. The trophic state of a freashwater ecosystem reflects its environmental quality [10]. Carlson's trophic state index (TSI) is the most widely used in freshwater bodies [11]. It, thus, becomes an important parameter for the assessment and management of surface water.

Kpassa reservoir has a vital value in north-east of Benin as it is the only water resource used for a sustainable water supply of Parakou city and around. Its water quality must then be constantly monitored to prevent its further degradation and promote its sustainable management. In addition since 2000 , the reservoir was invaded by aquatic plants. This abnormal situation induced many studies on the water quality parameters related to eutrophication process [12] [13]. The physico-chemical properties and the trophic state of the reservoir have been investigated by [12] over the period of 2003 to 2006. Similar work was made by [13] in 2010. However, there is a lack of recent data on these characteristics of the reservoir. A continuous monitoring of water quality is very 
essential to determine the state of pollution in our rivers [8] [14] [15] and to promote their sustainable management. The present study aimed to update physical and chemical knowledge of Kpassa reservoir including its trophic status.

\section{Materials and Methods}

\subsection{Study Area}

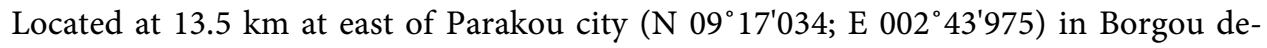
partment, Kpassa reservoir on Okpara with an area of 190 ha [16] (Figure 1) has mainly the role to supply the 254,254 inhabitants [17] of Parakou in drinking water. Parakou city is located at $\mathrm{N} 09^{\circ} 21^{\prime}$ and $\mathrm{E} 02^{\circ} 36^{\prime}$ in north-east of Benin, at $450 \mathrm{~km}$ from the economic capital Cotonou and at an average altitude of $350 \mathrm{~m}$ [12]. Okpara is one of the tributaries of river Ouémé of Benin [18].

The volume of water available in Kpassa reservoir is estimated at 8.2 million $\mathrm{m}^{3}$, either original volume of 9.4 million $\mathrm{m}^{3}$ obtained in 1972 decreased by 1.2 million $\mathrm{m}^{3}$ of sediment estimated in 2014 [19]. The reservoir is deep and shallow at some locations

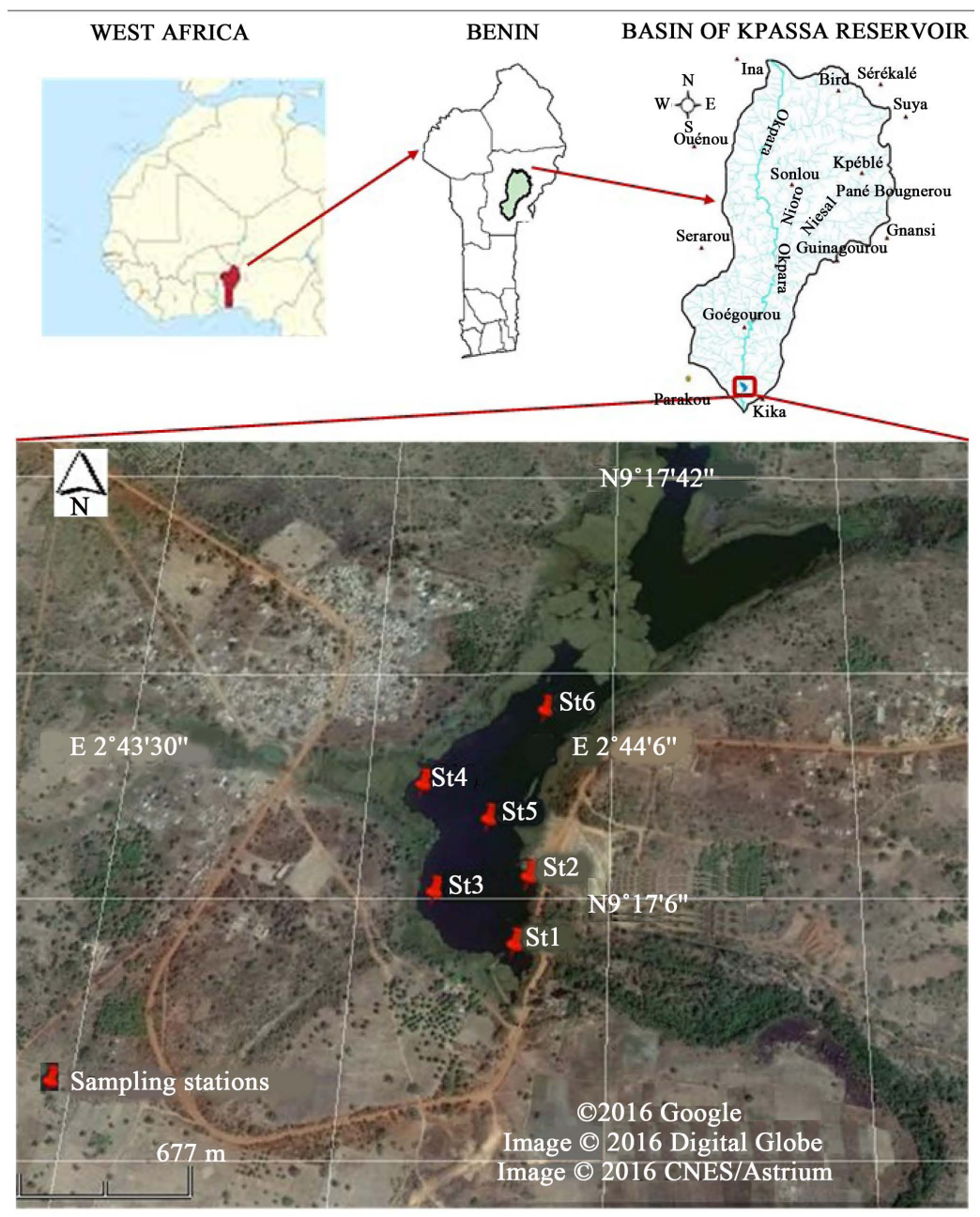

Figure 1. Map of Kpassa reservoir showing the location of the sampling stations. 
with depth varies between 1.5 and $8.5 \mathrm{~m}$. It is cover on about $90 \%$ of its surface by aquatic plants [20]. Kpassa reservoir basin is under the influence of Soudanian wet tropical climate [16]. The rainy season go often from May to October and the dry season from November to April. The area is also under the influence of the continental alizé called harmattan [12].

\subsection{Sampling}

Water samples were taken at $30 \mathrm{~cm}$ from the surface at eighteen stations each two months during the period from August 2014 to February 2015. Six stations were selected based on their accessibility and the potential pollution sources localization, and each one was then subdivided in three substations to densify the sampling network. Station I (St1) was closer to the raw water pumping point of the national water company; station II (St2) was closer to the East shore of the reservoir where cultural practices was made; stations III (St3) and IV (St4) were located along the West shore of the reservoir near Kpassa village; Station V (St5) was located in the middle of the reservoir and station VI (St6) in upstream of the reservoir.

\subsection{Analytical Methods}

Water turbidity (Turb), temperature (Temp), pH, Dissolved Oxygen (DO) and Electrical conductivity (Cond) were measured in situ using Water quality meter WQC-24 (TOA DKK Corporation), water transparency (SD) using secchi disk, Total Dissolved Solid (TDS) using conductimeter WTW 3210 SET 1 and suspended matter (Susp) was measured using portable HACH DR890 colorimeter.

The HACH DR2800 spectrophotometer was used to analyze nitrate $(\lambda=400 \mathrm{~nm})$, nitrite $(\lambda=507 \mathrm{~nm})$, ammonia $(\lambda=4655 \mathrm{~nm})$, orthophosphate $(\lambda=880 \mathrm{~nm})$, total phosphorous $(\lambda=880 \mathrm{~nm})$, and silica $(\lambda=815 \mathrm{~nm})$, according to the [21] methods. The organic matter concentration (oxyd) was determined by permanganate oxydability method [22] and the content of chlorophyll $a$ according to [23] method.

\subsection{Eutrophication Limiting Factor Identification}

$\mathrm{N} / \mathrm{P}$ ratio was used to identify the eutrophication limiting element. $\mathrm{N}$ and $\mathrm{P}$ concentrations was calculated using $\mathrm{NO}_{3}^{-}, \mathrm{NO}_{2}^{-}, \mathrm{NH}_{4}^{+}$and $\mathrm{PO}_{4}^{3-}$ concentrations as follow:

$$
\begin{gathered}
\mathrm{N}=\mathrm{NO}_{3}^{-}+\mathrm{NO}_{2}^{-}+\mathrm{NH}_{4}^{+} \\
\mathrm{P}=\mathrm{PO}_{4}^{3-}
\end{gathered}
$$

The obtained N/P ratio data were compared with the standard [24] ratio $(\mathrm{N} / \mathrm{P}=$ $16 / 1$ ). Nitrogen or phosphorus is the limiting factor respectively if N/P ratio value is lower or upper than $16 / 1$.

\subsection{Trophic State Classification}

The trophic state of the reservoir was estimated using [11] trophic state index (TSI). Three Carlson's TSI was firstly calculated with phytoplankton biomass estimated indi- 
rectly by chlorophyll-a pigment concentrations $\left(\mathrm{TSI}_{\mathrm{Chl}_{-\mathrm{a}}}\right)$, water transparency by the use of Secchi depth $\left(\mathrm{TSI}_{\mathrm{SD}}\right.$ ) and total phosphorus concentration $\left(\mathrm{TSI}_{\mathrm{TP}}\right)$, according to the following equations:

$$
\begin{gathered}
T_{\text {Chla }}=30.6+9.81 \times \ln (\text { Chla }) \\
T S I_{S D}=60-14.41 \times \ln (S D) \\
T S I_{T P}=4.15+14.42 \times \ln (T P)
\end{gathered}
$$

The overall Carlson's TSI was then calculated as the average value of TSI $_{\text {Chl-a, }}$ TSI $I_{S D}$ and $\mathrm{TSI}_{\mathrm{TP}}$ as follows:

$$
T S I=\left(T S I_{\text {Chla }}+T S I_{S D}+T S I_{T P}\right) / 3
$$

TSI ranges from 0 to 100 . TSI values less than 40 correspond to oligotrophic conditions, while between 40 and 50 for mesotrophic and between 50 and 70 for eutrophic. TSI values greater than 70 are associated with hypertrophic conditions.

\subsection{Statistical Analysis}

Statistical analysis was made using the following tests:

- Descriptive statistics to obtain average value, median, standard deviation, minimum, maximum, range, of all measured parameters.

- Pearson and Spearman correlations to determinate the significance of relations between certain parameters.

- ANOVA and Kruskal-Wallis Test to compare sampling locations with each other. The analysis of variance was used after verify the normality of variables (One-Sample Kolmogorov-Smirnov Test) and the homogeneity of variances (Levene Test). When these conditions are not verified, ANOVA was not used but the Kruskal-Wallis Test.

The charts and the statistical tests were generated using SPSS (Statistical Package for the Social Sciences) software version 16.0.

\section{Results and Discussion}

The descriptive statistics of the limnological characteristics of Kpassa reservoir are shown in Table 1. $\mathrm{pH}$ is the standard measure of how acidic or alkaline a solution is [2]. When $\mathrm{pH}$ is below 4 , it creates acid pollution resulting in destruction of most of the vertebrates and microorganism [25]. The $\mathrm{pH}$ of Kpassa reservoir was found to have a mean value of 6.54. It tended to be acidic (min 4.65) in the wet season (August) at station St1-2 and neutral (max 7.30) in the dry season (February) at station St4-1. These result showed that the nature of the water of Kpassa reservoir is allowable for aquatic life. In comparison to the study of [12], the mean $\mathrm{pH}$ value in the present study was greater by 0.34 .

The water temperature plays an important role in the solubility of salts and gases. It is one of the most significant parameters which control inborn physical qualities of water [26]. Water temperature values fluctuated between $25.1^{\circ} \mathrm{C}$ in December (dry season) at station St4-3 and $29.9^{\circ} \mathrm{C}$ in February (dry season) at station St5-2. High values of 
Table 1. Descriptive statistics of physico-chemical parameters of water quality.

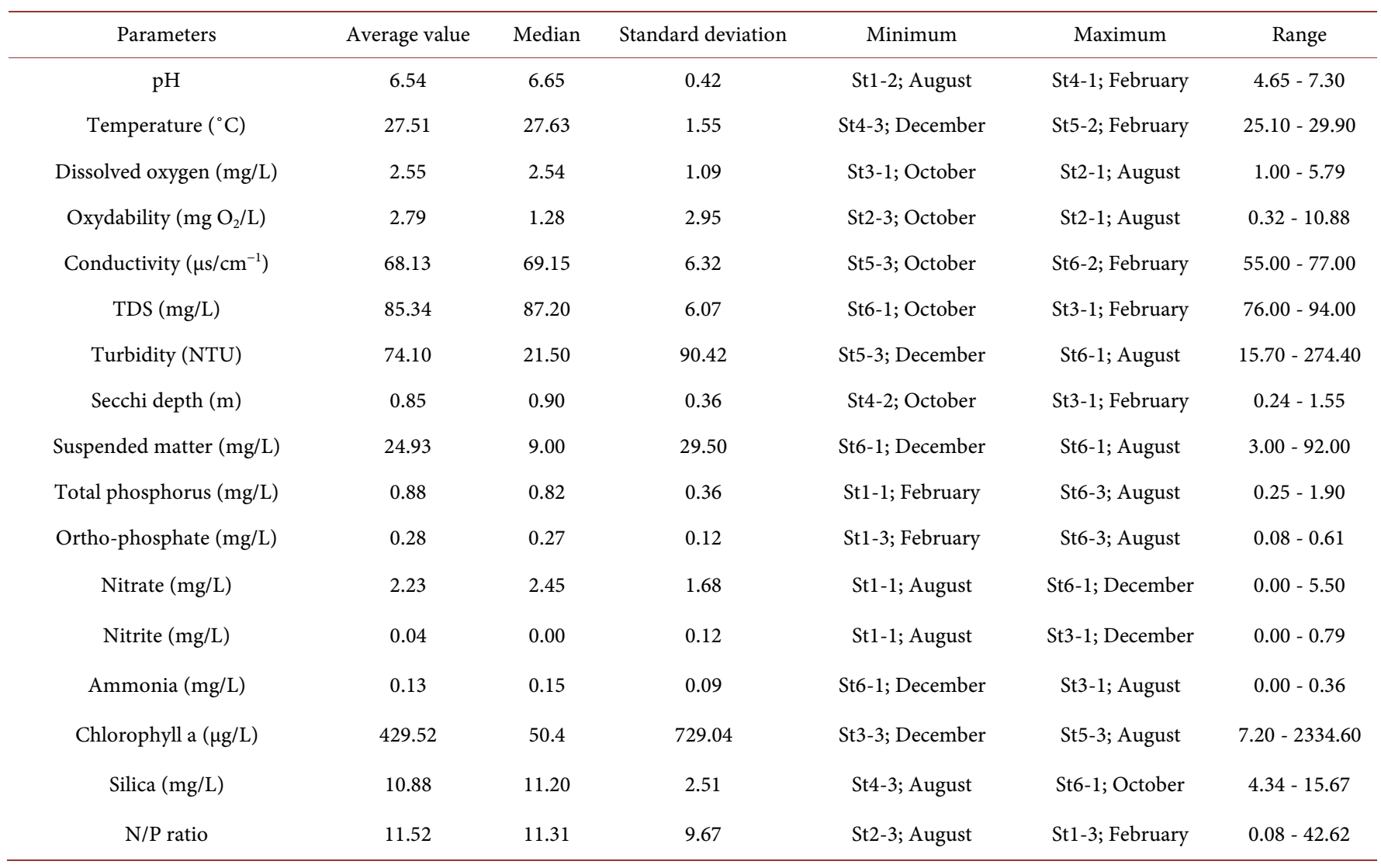

temperature were characteristic of the dry season but the lowest temperature recorded in December is due to the prevalence of air mass called Harmattan characterized by very cold temperatures. According to [27], temperatures higher than $15^{\circ} \mathrm{C}$ favor the development of microorganisms and activate chemical reactions. Temperature which occurs in Kpassa reservoir during the whole sampling period is thus favorable for algal growth.

Dissolved oxygen is an important parameter to assess the waste assimilative capacity of the waters [28]. The maxima $(5.79 \mathrm{mg} / \mathrm{L})$ was observed during the wet season (in August) at station St2-1 and the minima (1 mg/L) during the end of the wet season (in October) at station St3-1 with a mean value of $2.55 \mathrm{mg} \cdot \mathrm{dm}^{-3}$. Considering the study of [12], there was a decrease of the mean value by 2.15 in the present study. At the end of wet season (October), dissolved oxygen decreased leading to hypoxic conditions. According to [29], the decrease of dissolved oxygen was mainly caused by the decomposition of organic compounds. Organic matter consumes oxygen for his decomposition. Thus dissolved oxygen depletion observed in October could be due to the decomposition of organic matter probably produced by the macrophyte which covered Kpassa reservoir on around $90 \%$ of his surface [30]. Organic matter concentration expressed by oxydability ranged from $0.32 \mathrm{mg} \mathrm{O}_{2} / \mathrm{L}$ in October (end of wet season) at station St2-3 to $10.88 \mathrm{mg} \mathrm{O}_{2} / \mathrm{L}$ in August (wet season) at station St2-1. 
Electrical conductivity is the measurement of the ability of a solution to carry electric current. Its ability is dependent upon the presence of ions in solution and its measurement is an excellent indicator of the total dissolved solid in matter [31]. Thus the significant correlation obtained between TDS and conductivity $(r=0.967$; $r=0.951)$ is normal (Table 2). The highest value of conductivity $(77 \mu \mathrm{S} / \mathrm{cm})$ was observed in February at upstream of the reservoir (Station St 6-2) and the lowest value $(55 \mu \mathrm{S} / \mathrm{cm})$ in October at the middle of the reservoir (Station St 5-3). These values were upper than that determined by [12] $(98 \mu \mathrm{S} / \mathrm{cm})$. Low levels of conductivity observed in the present work could be due to the study period. Such period is characterized by little or no inflow which carried sediment and agricultural waste from the catchment area to increase the ion concentration in the reservoir.

TDS is causing by dissolved cation and anion species [32]. The freshwater had the value of TDS smaller than $1000 \mathrm{mg} / \mathrm{L}$ [33]. In Kpassa reservoir, TDS ranged from 76 $\mathrm{mg} \cdot \mathrm{dm}^{-3}$ in October at station St6-1 to $94 \mathrm{mg} / \mathrm{L}$ in February at station St3-1 with 85.34 $\mathrm{mg} / \mathrm{L}$ as mean value. This obtained data was tenfold smaller than the standard value above mentioned.

Turbidity of water is the presence of suspended and partial dissolved material in water sources [33]. Presence of decaying organic matter could also be attributed as the

Table 2. Pearson correlation (r) (lower triangle) and Spearman correlation (rs) (upper triangle) of the physico-chemical parameters of water.

\begin{tabular}{|c|c|c|c|c|c|c|c|c|c|c|c|c|c|c|c|c|c|}
\hline & SD & Turb & Temp & $\mathrm{pH}$ & DO & Cond & TDS & Susp & $\mathrm{NO}_{3}^{-}$ & $\mathrm{NO}_{2}^{-}$ & $\mathrm{NH}_{4}^{+}$ & $\mathrm{PO}_{4}^{3-}$ & $\mathrm{TP}$ & $\mathrm{SiO}_{2}$ & Oxyd & Chl a & $\mathrm{N} / \mathrm{P}$ ratio \\
\hline SD & 1.000 & -0.820 & 0.179 & $0.749^{* *}$ & & $0.749^{\star *}$ & $0.729^{\star *}$ & $-0.819^{\star *}$ & ${ }^{*} 0.768^{\star *}$ & 0.042 & & & +0.48 & * $0.322^{\star *}$ & & $*-0$ & $0.749^{* *}$ \\
\hline Turb & $-0.741^{\star *}$ & 1 & & $-0.607^{\star *}$ & $0.334^{\star *}$ & $-0.565^{\star *}$ & $-0.521^{\star *}$ & * $0.793^{\star *}$ & $-0.766^{\star *}$ & $-0.293^{\star}$ & 0.168 & $0.517^{\star *}$ & & $-0.449^{* *}$ & * $0.665^{\star *}$ & $0.663^{* *}$ & $-0.776^{* *}$ \\
\hline Temp & 0.190 & $-0.250^{*}$ & 1 & 0.041 & $-0.240^{*}$ & 0.033 & 0.048 & 0.074 & 0.041 & $-0.507^{\star *}$ & $+0.518^{\star *}$ & -0.021 & -0.033 & 0.038 & -0.149 & -0.062 & -0.015 \\
\hline $\mathrm{pH}$ & $0.689^{* *}$ & $-0.735^{\star *}$ & 0.114 & 1 & 0.107 & $0.640^{\star *}$ & $0.658^{* *}$ & $-0.766^{\star *}$ & $+0.658^{\star *}$ & 0.161 & -0.184 & $-0.424^{* *}$ & $-0.442^{\star *}$ & $0.265^{\star}$ & $-0.384^{\star *}$ & ${ }^{*}-0.464^{* *}$ & $0.652^{\star *}$ \\
\hline DO & -0.224 & $0.637^{\star *}$ & $-0.245^{\star}$ & $-0.241^{\star}$ & 1 & $0.295^{\star}$ & $0.346^{* *}$ & 0.166 & $-0.330^{* *}$ & 0.108 & 0.065 & $0.296^{*}$ & $0.282^{*}$ & $-0.330^{* *}$ & $* 0.602^{* *}$ & $0.449^{\star *}$ & $-0.267^{\star}$ \\
\hline Cond & $0.664^{\star *}$ & -0.220 & -0.052 & $0.383^{\star *}$ & $0.314^{\star *}$ & 1 & $0.951^{\star *}$ & $-0.644^{\star *}$ & $0.556^{* *}$ & 0.096 & -0.051 & $-0.289^{*}$ & $-0.318^{*}$ & 0.162 & -0.169 & $-0.233^{*}$ & $0.547^{* *}$ \\
\hline TDS & $0.726^{\star *}$ & $-0.276^{*}$ & 0.071 & $0.434^{* *}$ & $0.271^{*}$ & $0.967^{\star *}$ & 1 & $-0.595^{\star *}$ & $0.484^{* *}$ & 0.065 & 0.001 & $-0.345^{\star *}$ & ${ }^{*}-0.374^{\star *}$ & 0.051 & -0.128 & -0.183 & $0.546^{* *}$ \\
\hline Susp & $-0.781^{\star \star}$ & $0.982^{\star *}$ & -0.174 & $-0.759^{\star *}$ & $0.555^{\star *}$ & $-0.303^{\star *}$ & $-0.351^{\star *}$ & 1 & $-0.839^{\star *}$ & $-0.287^{\star}$ & $0.330^{\star *}$ & $0.543^{\star *}$ & $0.546^{* *}$ & $-0.413^{\star *}$ & $* 0.602^{\star *}$ & $0.656^{\star *}$ & $-0.831^{\star *}$ \\
\hline $\mathrm{NO}_{3}^{-}$ & $0.781^{\star *}$ & $-0.778^{\star *}$ & 0.041 & $0.661^{\star *}$ & $-0.354^{* *}$ & $* 0.518^{\star *}$ & $0.535^{\star *}$ & $-0.813^{\star *}$ & 1 & 0.215 & -0.132 & $-0.377^{\star *}$ & ${ }^{*}-0.385^{\star *}$ & $\star 0.470^{* *}$ & $-0.603^{* *}$ & * $-0.656^{* *}$ & $0.809^{* *}$ \\
\hline $\mathrm{NO}_{2}^{-}$ & 0.110 & -0.184 & $-0.343^{* *}$ & 0.195 & 0.074 & 0.127 & 0.094 & -0.199 & 0.180 & 1 & $-0.473^{\star *}$ & +-0.155 & -0.121 & 0.130 & -0.068 & $-0.306^{\star *}$ & $0.262^{*}$ \\
\hline $\mathrm{NH}_{4}^{+}$ & -0.101 & 0.184 & $0.486^{\star *}$ & -0.131 & 0.106 & -0.142 & -0.063 & 0.223 & -0.171 & $-0.380^{* *}$ & 1 & $0.340^{\star *}$ & $0.330^{\star *}$ & 0.006 & $0.238^{*}$ & $0.290^{*}$ & -0.183 \\
\hline $\mathrm{PO}_{4}^{3-}$ & $-0.494^{\star *}$ & $0.619^{* *}$ & -0.094 & $-0.427^{\star *}$ & $0.380^{* *}$ & $-0.237^{\star}$ & $-0.311^{\star *}$ & $* 0.630^{* *}$ & $-0.424^{\star *}$ & -0.225 & $0.348^{\star *}$ & 1 & $0.988^{* *}$ & -0.161 & $0.402^{\star *}$ & $0.475^{\star *}$ & $-0.786^{\star *}$ \\
\hline TP & $-0.492^{\star *}$ & $0.581^{\star *}$ & -0.099 & $-0.428^{\star *}$ & $0.334^{\star *}$ & $-0.270^{*}$ & $-0.343^{* *}$ & $\star 0.599^{* *}$ & $-0.418^{\star *}$ & -0.196 & $0.331^{\star *}$ & $0.989^{\star *}$ & 1 & -0.161 & $0.402^{\star *}$ & $0.450^{* *}$ & $-0,788^{\star *}$ \\
\hline $\mathrm{SiO}_{2}$ & $0.393^{\star *}$ & $-0.491^{\star *}$ & 0.055 & $0.361^{* *}$ & $-0.320^{* *}$ & 0.127 & 0.119 & $-0.487^{\star *}$ & ${ }^{*} 0.500^{* *}$ & 0.134 & 0.049 & -0.186 & -0.186 & 1 & $-0.366^{* *}$ & ${ }^{*}-0.321^{* *}$ & $0,376^{* *}$ \\
\hline Oxyd & $-0.685^{\star *}$ & $0.924^{\star *}$ & -0.215 & $-0.671^{\star *}$ & $0.672^{\star *}$ & -0.204 & $-0.254^{*}$ & $0.919^{* *}$ & $-0.751^{\star *}$ & -0.151 & 0.231 & $0.584^{\star *}$ & $0.584^{\star *}$ & $-0.446^{\star *}$ & 1 & $0.652^{\star \star}$ & $-0.551^{\star *}$ \\
\hline Chl a & $-0.683^{\star *}$ & $0.884^{\star *}$ & -0.123 & $-0.529^{* *}$ & $0.630^{* *}$ & -0.174 & $-0.221^{*}$ & $0.879^{* *}$ & $-0.710^{\star *}$ & -0.159 & $0.250^{*}$ & $0.591^{\star *}$ & $0.559^{* *}$ & $-0.373^{\star *}$ & * $0.859^{\star *}$ & 1 & $-0.625^{\star *}$ \\
\hline $\begin{array}{l}\mathrm{N} / \mathrm{P} \\
\text { ratio }\end{array}$ & $0.686^{* *}$ & $-0.679^{\star *}$ & -0.004 & $0.560^{\star *}$ & $-0.255^{*}$ & $0.541^{\star *}$ & $0.585^{\star *}$ & $-0.714^{\star *}$ & $0.786^{\star *}$ & $0.303^{\star *}$ & -0.196 & $-0.727^{\star \star}$ & ${ }^{*}-0.729^{* *}$ & * $0.356^{\star *}$ & $-0.644^{* *}$ & $*-0.617^{\star *}$ & 1 \\
\hline
\end{tabular}

**: Correlation is significant at the 0.01 level; *: Correlation is significant at the 0.05 level. 
cause of the turbidity level [34]. The significant correlation noted between turbidity and suspended matter $(\mathrm{r}=0.982 ; \mathrm{rs}=0.793)$ and turbidity and oxydability $(\mathrm{r}=0.924 ; \mathrm{rs}=$ 0.665) confirm these observations (Table 2). Turbidity has also a significant correlation with chlorophyll a $(r=0.884 ; r s=0.663)$ probably because phytoplankton contribute to the production of organic matter (Table 2). During the study period, its range was found very wide from 15.70 NTU to 274.40 NTU. These values were respectively recorded in December at station St5-3 and August at station St6-1.

Transparency values express by secchi depth ranged from $0.24 \mathrm{~m}$ in October at station St4-2 to $1.55 \mathrm{~m}$ in February at station St3-1. High density of phytoplankton and high concentration of suspended matter are the main factors which contribute to reduce water transparency. According to [35], suspended matter contributes more to reduced transparency than phytoplankton density. The negative and strong correlation between transparency and chlorophyll a $(\mathrm{r}=-0.683$; $\mathrm{rs}=-0.535)$ and transparency and suspended matter $(r=-0.781$; $r s=-0.819)$ confirm this remark in Kpassa reservoir (Table 2).

Suspended matter concentration fluctuated between $3 \mathrm{mg} / \mathrm{L}$ in December (dry season) at station St6-1 and $92 \mathrm{mg} / \mathrm{L}$ in August (wet season) at the same station. Suspended matter was essentially due to erosion in the catchment area and to the presence of large quantities of agricultural waste carried in by leaching from the fields [36]. This was confirmed by the significant correlation between suspended matter and nitrate $(r=$ -0813; rs $=-0.839$ ) (Table 2). As oxydability and chlorophyll a also influence suspended matter, the significant correlations between suspended matter and oxydability $(\mathrm{r}=0.919 ; \mathrm{rs}=0.602)$ and suspended matter and chlorophyll $\mathrm{a}(\mathrm{r}=0.879 ; \mathrm{rs}=0.656)$ were expected (Table 2).

Agricultural activities are considered as the major provider of nutrients in lakes, especially in the Mediterranean region, where agricultural sector comprises an important economic factor [37]. Nutrients are responsible for many problems not only for environment but also for human health. We have the total phosphorus (TP) concentrations in the range of $0.25 \mathrm{mg} / \mathrm{L}$ (in February-dry season) and $1.90 \mathrm{mg} / \mathrm{L}$ (in August-wet season). Orthophosphate is the only form of phosphorus available for algae photosynthesis [35]. Its concentrations varied from $0.08 \mathrm{mg} / \mathrm{L}$ in February during dry season to 0.61 $\mathrm{mg} / \mathrm{L}$ in August during wet season. The maximum values of nitrate $(5.50 \mathrm{mg} / \mathrm{L})$, nitrite $(0.79 \mathrm{mg} / \mathrm{L})$ and ammonia $(0.36 \mathrm{mg} / \mathrm{L})$ were respectively detected in dry season (December and February) and wet season (August). Nitrate was not recorded in wet season because of the dilution effect generated by streaming water coming from the catchment area as mentioned by previous study [12]. Most values of nitrite were also undetected throughout the study period. Nutrients disponibility in Kpassa reservoir is principally link to the progression of agricultural land in Okpara basin [38]. This basin is known for its agricultural vocation. Intense agricultural activity is practice by around $80 \%$ of the inhabitant of the study region and it is known that agricultural runoff contains high levels of phosphate, nitrogen, and pesticides. The main environment impact associated with nutrients is eutrophication. About it, previous studies [12] and [13] classified 
Kpassa reservoir into eutrophic and hypertrophicc categories on the basis of phosphorus and nitrate concentrations.

Phytoplankton biomass (Chlorophyll a) ranged from $7.20 \mu \mathrm{g} / \mathrm{L}$ in December at station St3-3 to $2334.6 \mu \mathrm{g} / \mathrm{L}$ in August at station St5-3. Nitrogen and phosphorus are generally considered as the main factors for the growth of algae [24] [39]. Noticed increase of chlorophyll a in August could be a consequence of phytoplankton nutrient absorption. Strong and negative correlation between nitrate and chlorophyll a concentrations $(\mathrm{r}=-0.710 ; \mathrm{rs}=-0.656)$ were found (Table 2$)$. This observation indicates the association between nitrogen nutrient pressure and phytoplankton response. Such association was not found between orthophosphate and chlorophyll a $(r=0.591 ; \mathrm{rs}=0.475)$ (Table 2).

Silica values were observed to be high $(15.67 \mathrm{mg} / \mathrm{L})$ in the month of October and minimun $(4.34 \mathrm{mg} / \mathrm{L})$ in August. The presence of silica throughout the sampling period could be due to the geochemical characteristics of the study area. Silica is an important constituents of different kinds of rock in Kpassa reservoir basin (57\% to 74\%) [12]. Since Silica can be a limiting nutrient for diatoms' growth [35], a strong correlation between $\mathrm{SiO}_{2}$ and chlorophyll $a$ is expected but Pearson and Spearman correlation coefficient $(r=-0.373 ; r s=-0.321)$ showed a weak relation between them in the present study.

The N/P ratio ranged from 0.08 to 42.62 . Most values were lower than Redfield's ratio of 16/1 [24] in wet season (August and October) indicated that nitrogen is the limiting factor of Kpassa reservoir eutrophication in this period. In dry season (December and February) the N/P ratio exceeded Redfield's ratio showing that the limiting element in this period was phosphorus. According to [12], N/P ratio in Kpassa reservoir ranged between 4 and 100 one year to another independently of the seasons. This provides one explanation on the fact that [13] identified different limiting factor in Kpassa reservoir during the dry season. There was a strong negative correlation between N/P ratio and chl $a(r=-0.617 ; \mathrm{rs}=-0.625)$ (Table 2). Similar result was found by [40] who showed on a series of lakes that the TN/TP ratio was negatively correlated with the chlorophyll a concentration.

The spatio-temporal variation of Carlson's trophic state index (TSI) is shown in Figure 2. TSI values fluctuated between 36 and 66 having an average of 47 which classifies Kpassa reservoir to the mesotrophic level. The minimum value correspond to an oligotrophic state while the maximum to a eutrophic state. During the wet season particularly in August, all values of TSI indicated the eutrophic status of Kpassa reservoir. Similar result was found by [12] who assessed the trophic state of the reservoir on the base of [41] classification. This result is different from those reported by [13] based on phosphorus and chlorophyll a values in water column. According to this author, Kpassa reservoir is hypertrophic. Over the rest of the study period, Kpassa reservoir trophic state is mesotrophic with a tendency to oligotrophic state. Most values of TSI were characteristic of mesotrophic conditions during this period.

P-probability of One-Sample Kolmogorov-Smirnov test and Levene test are shown in Table 3. ANOVA and Kruskal-Wallis test showed that there were no significant differ- 
Table 3. p-probability (Sig.) of one-sample Kolmogorov-Smirnov test and Levene test.

\begin{tabular}{|c|c|c|}
\hline Parameters & Kolmogorov-Smirnov Test Sig. & Levene Test Sig. \\
\hline $\mathrm{pH}$ & 0.001 & 0.128 \\
\hline Temperature $\left({ }^{\circ} \mathrm{C}\right)$ & 0.268 & 0.428 \\
\hline Dissolved oxygen (mg/L) & 0.591 & 0.858 \\
\hline Oxydability (mg/L) & 0.000 & 0.996 \\
\hline Conductivity $(\mu \mathrm{s} / \mathrm{cm})$ & 0.088 & 0.999 \\
\hline TDS (mg/L) & 0.091 & 1.000 \\
\hline Turbidity (NTU) & 0.000 & 1.000 \\
\hline Secchi depth (m) & 0.584 & 0.905 \\
\hline Suspended matter $(\mathrm{mg} / \mathrm{L})$ & 0.000 & 1.000 \\
\hline Total phosphorus (mg/L) & 0.727 & 0.053 \\
\hline $\mathrm{PO}_{4}^{3-} \quad(\mathrm{mg} / \mathrm{L})$ & 0.673 & 0.045 \\
\hline $\mathrm{NO}_{3}^{-}(\mathrm{mg} / \mathrm{L})$ & 0.055 & 0.406 \\
\hline $\mathrm{NO}_{2}^{-}(\mathrm{mg} / \mathrm{L})$ & 0.000 & 0.000 \\
\hline $\mathrm{NH}_{4}^{+} \quad(\mathrm{mg} / \mathrm{L})$ & 0.148 & 0.944 \\
\hline $\mathrm{SiO}_{2}(\mathrm{mg} / \mathrm{L})$ & 0.938 & 0.124 \\
\hline Chla $(\mathrm{mg} / \mathrm{L})$ & 0.000 & 0.323 \\
\hline $\mathrm{N} / \mathrm{P}$ ratio & 0.266 & 0.730 \\
\hline
\end{tabular}

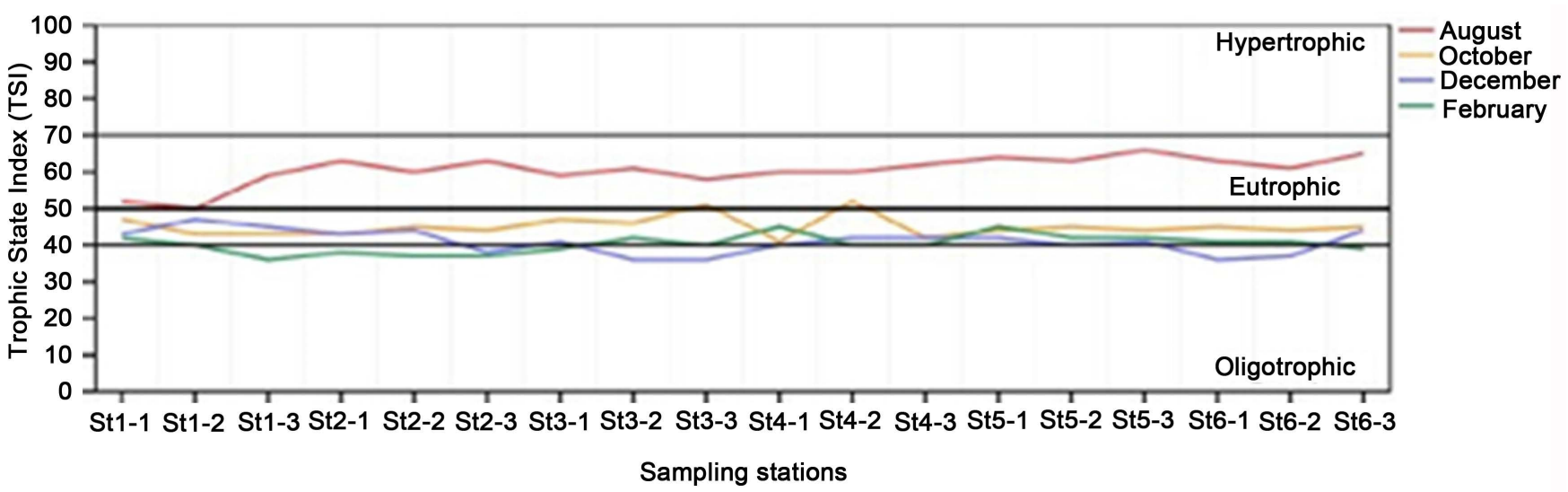

Figure 2. Spatial variation of Carlson's Trophic State Index (TSI) at different month in Kpassa reservoir with limiting degrees of trophic status.

rences between sampling stations (Table 4). This result indicated that Kpassa reservoir is not horizontally stratified and this could be due to the fact that the reservoir is influenced by diffuse pollution (agricultural pollution) and climatic condition (air temperature). Previous study showed the vertical stratification of Kpassa reservoir [12].

\section{Conclusion}

The present investigation showed that the physico-chemical properties of Kpassa reservoir were mainly influenced by agricultural non-point source pollution. The second 
Table 4. p-probability (Sig.) of analysis of variance (ANOVA) and Kruskal-Wallis test.

\begin{tabular}{|c|c|}
\hline Parameters & ANOVA Sig. \\
\hline Temperature $\left({ }^{\circ} \mathrm{C}\right)$ & 1.000 \\
\hline Dissolved oxygen $(\mathrm{mg} / \mathrm{L})$ & 0.997 \\
\hline Conductivity $(\mu \mathrm{s} / \mathrm{cm})$ & 1.000 \\
\hline TDS (mg/L) & 1.000 \\
\hline Secchi depth (m) & 1.000 \\
\hline Total phosphorus (mg/L) & 0.668 \\
\hline $\mathrm{PO}_{4}^{3-} \quad(\mathrm{mg} / \mathrm{L})$ & 0.731 \\
\hline $\mathrm{NO}_{3}^{-}(\mathrm{mg} / \mathrm{L})$ & 0.962 \\
\hline $\mathrm{NH}_{4}^{+} \quad(\mathrm{mg} / \mathrm{L})$ & 0.992 \\
\hline $\mathrm{SiO}_{2}(\mathrm{mg} / \mathrm{L})$ & 0.669 \\
\hline $\mathrm{N} / \mathrm{P}$ ratio & 0.998 \\
\hline Parameters & Kruskal-Wallis Test Sig. \\
\hline $\mathrm{pH}$ & 1.000 \\
\hline Oxydability (mg/L) & 0.960 \\
\hline Turbidity (NTU) & 1.000 \\
\hline Suspended matter $(\mathrm{mg} / \mathrm{L})$ & 1.000 \\
\hline $\mathrm{NO}_{2}^{-}(\mathrm{mg} / \mathrm{L})$ & 0.665 \\
\hline Chla (mg/L) & 0.995 \\
\hline
\end{tabular}

most important impact factor was the climatic conditions. Organic matter produced by the macrophyte was found to have a strong impact on dissolved oxygen inducing hypoxic conditions in Kpassa reservoir at the end of wet season. Results of trophic state assessment showed the eutrophic state of Kpassa reservoir in August. In regard to the surface covered by the macrophyte during this period, the eutrophic state of the reservoir was expected. From October to February, the reservoir trophic state fluctuated between mesotrophic and oligotrophic state. Besides the mechanical removal of the plants, other measures of restoration of the reservoir must be implemented for its safeguarding. This study suggests the restriction or the removal of the use of chemical fertilizers in agricultural activities in Kpassa reservoir basin. Differences in the concentration of physico-chemical parameters between sampling stations are not statistically significant. In addition to horizontal sampling, vertical sampling at surface and different depth is advised for future study in Kpassa reservoir.

\section{Acknowledgements}

This research work was supported by $\mathrm{PhD}$ grant from the Netherland Program of Reinforcement of Capacities in Post-secondary Teaching (Project NICHE BEN 167). Special thanks to all the members of the Project especially to Pr Marc T. KPODEKON, 
Coordinator of project NICHE BEN 167 and Pr Euloge K. AGBOSSOU, Director of "Institut National de l'Eau" (INE) for their excellent management. Particular thanks to Pr Moussa BOUKARI, Director of "Laboratoire d'Hydrologie Appliquée” (LHA) for his special support. We are grateful to Dr Dieudonné ZOGO, Director of "Société Nationale des Eaux du Bénin Parakou" (SONEB Parakou) for his valuable contribution. We also thank Dr Lyde TOMETIN, Mohamed BOURE, Akilou SOCOHOU and Gaël SOUNOUVO for field and laboratory assistance.

\section{References}

[1] Akpoborie, T., Egbo, S.H.O., Ebenuwa, C.C. and Emeshili, E.M. (2008) Comparative Study of the Satchet Water in Asaba Metropolis, South-South, Nigeria. Proceeding of International Conference of the Chemical Society of Nigeria, Effurun, 22-26 September 2008, 189-192.

[2] Dimowo, B.O. (2013) Assessment of Some Physico-Chemical Parameters of River Ogun (Abeokuta, Ogun State, Southwestern Nigeria) in Comparison with National and International Standards. International Journal of Aquaculture, 3, 79-84.

[3] Sundar, M.L. and Saseetharan, M.K. (2008) Ground Water Quality in Coimbatore, Tamil Nadu along Noyyal River. Journal of Environmental Science and Engineering, 50, 187-190.

[4] Rode, M. and Suhr, U. (2007) Uncertainties in Selected River Water Quality Data. Hydrology and Earth System Sciences, 11, 863-874.

https://doi.org/10.5194/hess-11-863-2007

[5] Pejman, A.H., Nabi Bidhendi, G.R., Karbassi, A.R., Mehrdadi, N. and Esmaeili Bid-Hendi, M. (2009) Evaluation of Spatial and Seasonal Variations in Surface Water Quality Using Multivariate Statistical Techniques. International Journal of Environmental Science and Technology, 6, 467-476. https://doi.org/10.1007/BF03326086

[6] Dz. U. 2005/239/2019 Ustawa Prawo Wodne z dnia 18 lipca 2001 r. [Water Law Act of 18th of July, 2001].

[7] Chmiel, S., Glowacki, S., Michalczyk, Z. and Sposob, J. (2009) Some Issues in the Assessment of Eutrophication of River Waters as a Consequence of the Construction of a Storage Reservoir (on the Example of the Bystrzyca River). Ecohydrology \& Hydrobiology, 9, 175179. https://doi.org/10.2478/v10104-010-0013-0

[8] Anonymous (1997) Water Analysis Hand Book. 3rd Edition, Hach Company, USA.

[9] Abdul-Razak, A., Asiedu, A.B., Entsua-Mensah, R.E.M. and de Graft-Johnson, K.A.A. (2009) Assessment of the Water Quality of the Oti River in Ghana. West African Journal of Applied Ecology, 15, 12 p.

[10] Kehayias, G. and Doulka, E. (2014) Trophic State Evaluation of a Large Mediterra-Nean Lake Utilizing Abiotic and Biotic Elements. Journal of Environmental Protection, 5, 17-28. https://doi.org/10.4236/jep.2014.51003

[11] Carlson, R.E. (1977) A Trophic State Index for Lakes. Limnology and Oceanography, 22, 361-369. https://doi.org/10.4319/lo.1977.22.2.0361

[12] Zogo, D. (2010) Study of the Elimination of Iron and Manganese at the Time of the Potabilisation of the Water of a Dam in the Course of Eutrophication: Case of Okpara at Parakou in Benin. PhD Dissertation, University of Abomey-Calavi, Abomey-Calavi.

[13] Tométin, A.S.L., Daouda, M., Zogo, N.D., Boukari, O. and Bawa, L.M. (2013) EuTrophication, Sediment Phosphorus Fractionation and Short Term Mobility Study in the 
Surface and Under Profile Sediment of a Water Dam (Okpara Dam, Benin, West Africa). Journal Applicant Science, Environment and Management, 17, 517-526.

[14] Dwivedi, S.L. and Pathak, V. (2007) A Preliminary Assignment of Water Quality Index to Andakini River, Chitrakoot. Indian Journal of Environtal Protection, 27, 1036-1038.

[15] Couillard, D. and Lefebvre, Y. (1985) Analysis of Water Quality Indices. Journal of Environmental Management, 21, 161-179.

[16] Assouma, K. (2008) Availability of Water for the Drinking Water Supply of the Urban Center of Parakou by 2025. DESS Dissertation, University of Abomey-Calavi, AbomeyCalavi.

[17] INSAE (2013) Provisional Results of the Fourth Census of the Population and the Dwelling. Cotonou.

[18] Suanon, F., Dimon, B., Mama, D. and Tométin, A.L. (2013) Study of the Sediments of the Dam of Okpara (Benin): Physico-Chemical Characterization and Speciation of Iron and Manganese. Journal of Water Resource and Protection, 5, 709-714. https://doi.org/10.4236/jwarp.2013.57071

[19] Brabant Water and SONEB (2014) AEP Parakou, Development Phase. Studies Report, Final Report, Parakou.

[20] PNE (2008) Note of Plea for the Rehabilitation and the Installation of a Concerted Management of Okpara Dam. Single Source of AEP of the Town of Parakou, Parakou.

[21] HACH (2005) DR LANGE 2800 Analysis Handbook. HACH Company World Headquarter, Germany.

[22] Legube, B., Merlet, N. and Brunet R. (2009) Jean Rodier Water Analysis Handbook. 9th Edition, Dunod, Paris.

[23] Lorenzen, G. (1967) Determination of Chlorophyll and Phaeopigments: SpectrophoTometric Equations. Limnology and Oceanography, 12, 343-346. https://doi.org/10.4319/lo.1967.12.2.0343

[24] Redfield, J.L., Ketchum, B.H. and Richards, F.A. (1963) The Influence of Organ-Isms on the Composition of Seawater. In: Hil, M.N., Ed., The Sea, Willey, New York, 26-77.

[25] Rao, G.S. and Rao, G.N. (2010) Study of Ground Water Quality in Greater Visakha-Patnam City, AP India. Journal of Environmental Science and Engineering, 52, 137-146.

[26] Hamaidi-Chergui, F., Errahmani, M.B., Benouaklil, F. and Hamaidi, M.S. (2013) Preliminary Study on Physico-Chemical Parameters and Phytoplankton of Chiffa River (Blida, Algeria). Journal of Ecosystems, 2013, Article ID: 148793. https://doi.org/10.1155/2013/148793

[27] Nait Merzoug, A. and Merazig, H. (2012) Water Pollution of Oued Medjerda in Alge-Rian Souk Ahras Region. In: Kostas, V. And Dimitra, V., Eds., Water Quality Monitoring and Assessment, InTech, Croatia, 527-540.

[28] Kumar, S., Ghosh, N.C., Singh, R.P., Sonkusare M.M., Singh, S. and Mittal, S. (2015) Assessment of Water Quality of Lakes for Drinking and Irrigation Purposes in Raipur City, Chhattisgarh, India. International Journal of Engineering Research and Applications, 5, 4249.

[29] Wang, X., Lu, Y., Han, J., He, G. and Wang, T. (2007) Identification of Anthropo-Genic Influences on Water Quality of Rivers in Taihu Watershed. Journal of Environmental Sciences, 19, 475-481. https://doi.org/10.1016/S1001-0742(07)60080-1

[30] Adejuwon, J.O. and Adelakun, M.A. (2012) Physiochemical and Bacteriological Analysis of Surface Water in Ewekoro Local Government Area of Ogun State, Nigeria: Case Study of 
Lala, Yobo and Agodo Rivers. International Journal of Water Resources and Environmental Engineering, 4, 66-72.

[31] Kapil, N. and Bhattacharyya, K.G. (2008) Bio-Monthly Variation of Wetland Water Quality: A Case Study with Deeper Bell, Assam, India. 16th National Symposium of Environment, Haryana, 16-18 July 2008, 166-170.

[32] Vaishnav, M.M., Janjala, R., Hait, M., Rahangdale, P.K. and Dewangan, S. (2016) Periodic Water Quality Monitoring of Surface Water in Korba District (C.G.) India. International Journal of Environmental Science and Development, 7, 698-702. https://doi.org/10.18178/ijesd.2016.7.9.865

[33] Rim-Rukeh, A., Ikhifa, G. and Okokoyo, P. (2007) Physico-Chemical Characteristics of Some Waters Used for Drinking and Domestic Purposes in the Niger Delta, Nigeria. Environmental Monitoring and Assessment, 128, 475-482. https://doi.org/10.1007/s10661-006-9340-4

[34] Ivankovic, A., Habul, E.V. and Knezovic, Z. (2011) Physico-Chemical Characteristics of Shallow, High Mountain Lake Blidinje (in a Karst Area of Bosnia and Herzegovina) with Emphasis on Its Trophic Status. International Journal of Oceanography and Hydrobiology, 40, 19-27. https://doi.org/10.2478/s13545-011-0025-4

[35] Akpan, E.R. and Offem, J.O. (2004) Seasonal Variation in Water Quality of the Cross River, Nigeria. Revue d Hydrobiologie Tropicale, 26, 95-103.

[36] Bertahas, I., Dimitriou, E., Karaouzas, I., Laschou, S. and Zacharias, I. (2006) Climate Change and Agricultural Pollution Effects on the Trophic Status of a Mediterranean Lake. Acta Hydrochimica et Hydrobiologica, 34, 349-359. https://doi.org/10.1002/aheh.200500637

[37] Boukari, O. (2012) Study of the Eutrophication of Okpara Dam at Kpassa (Tchaourou). Master Dissertation, University of Abomey-Calavi, Abomey-Calavi.

[38] Fong, P., Zedler, J.B. and Donohoe, R.M. (1993) Nitrogen vs. Phosphorus Limitation of Algal Biomass in Shallow Coastal Lagoons. Limnology and Oceanography, 38, 906-923. https://doi.org/10.4319/lo.1993.38.5.0906

[39] Johnson, M.W., Heck, K.I. and Fourqurean, J.W. (2006) Nutrient Content of Seagrasses and Epiphytes in the Northern Gulf of Mexico: Evidence of Phosphorus and Nitrogen Limitation. Aquatic Botany, 85, 103-111. https://doi.org/10.1016/j.aquabot.2006.02.003

[40] Forsberg, C. and Ryding, S.O. (1980) Eutrophication Parameters and Trophic State Indices in 30 Swedish Waste-Receiving Lakes. Archiv fur Hydrobiologie, 89, 189-207.

[41] OECD (1982) Eutrophication of Waters: Monitoring, Assessment and Control. Paris. 